\title{
Mendesain Madrasah di Tanah Papua: Sebuah Kasus Kota Jayapura
}

\author{
Nurudin
}

Nurudin, M.Si adalah

Peneliti Puslitbang Pendidikan Agama dan

Keagamaan - Badan

Litbang dan Diklat Kementerian Agama RI $* * * * *$

Naskah diterima 5 September 2011. Revisi pertama, 25 September 2011, revisi kedua, 14 Oktober 2011 dan revisi terakhir 25 Nopember

\section{Abstract}

The development of Islamic education for marginalized community should be handled in different way from any other that has better access to adequate education. In some regions where the people have little access to development and are isolated and far from passable infrastructure such as Jayapura, the Islamic education, called Madrasah, is addressed to focus on self-empowerment especially to solve their facing problems in a more independent manner while perceiving either the problem analysis or expected requirement level. To this end, the government may play a companion role to provide both direct and indirect support toward an improved Madrasah education for the community in question. Therefore, a greater public participation can be realized through tirelessly mainta- 
ined cultural values of self-reliance and mutual help so that the developed model will become a people's education. Madrasah in marginal communities would provide public participation as part of the development for the better.

Keywords: madrasah, marginal, access, development.

\section{Abstrak}

Pengembangan pendidikan madrasah di komunitas marjinal sudah sepantasnya berbeda perlakuannya dengan komunitas lain yang lebih banyak mendapatkan akses pendidikan yang memadai. Di komunitas yang masyarakatnya sulit mendapatkan akses pembangunan, terpencil, dan jauh dari infrastruktur yang memadai, seperti Jayapura maka layanan pendidikan madrasahnya lebih diarahkan pada pemberdayaan diri, terutama untuk memecahkan persoalannya sendiri secara lebih mandiri dengan melihat analisis persoalan dan tingkat kebutuhan yang diharapkan. Dalam posisi ini, pemerintah bertindak: sebagai pendamping yang akan memberikan support secara langsung maupun tidak langsung terhadap peningkatan pendidikan madrasah di komunitas marjinal. Oleh karena itu, tingkat pelibatan masyarakat lebih besar karena kultur yang dimilikinya masih kuat nilai-nilai keswadayaan dan gotong-royong sehingga model madrasah yang dikembangkan merupakan pendidikan masyarakat. Madrasah di komunitas marjinal akan memberikan partisipasi masyarakat sebagai bagian dari pengembangan ke arah yang lebih baik.

Kata Kunci: madrasah, marjinal, akses, pengembangan.

\section{PENDAHULUAN}

Pendidikan merupakan kebutuhan setiap warganegara tanpa mengenal batas waktu dan tempat. Sebagaimana termaktub dalam konstitusi, negara memiliki tanggung jawab yang besar dalam upaya pencerdasan kehidupan bangsa bagi warga negaranya. Konstitusi menegaskan bahwa warga negara memiliki hak yang sama dalam memperoleh akses terhadap pendidikan. Dalam kaitan ini, negara tidak boleh bertindak diskriminatif terhadap warga negara dalam memperoleh akses pendidikan. Konsepsi ini 
menegaskan bahwa hak-hak warga negara dijamin sepenuhnya oleh konstitusi dan proses penyelenggaraan pendidikan (nasional) harus berjalan secara humanis dan berkeadilan.

Berkaitan dengan hal di atas, salah satu ragam perbedaan yang mendasar dalam pendidikan kita adalah aspek perbedaan status sosial. Di negeri ini, kita mengerti bahwa warga negara dalam suatu bangsa tentu memiliki status sosial yang berbeda, ada kalangan kaya dan sebaliknya ada juga yang miskin atau termarjinalkan. Di sinilah peran pendidikan harus mampu memberikan dan mengakomodir warganegara yang berbeda status sosial untuk mendapatkan hak-hak pendidikan yang berkualitas. Tidak beralasan jika pendidikan hanya diorientasikan pada pemenuhan hak-hak warga negara tertentu.

Sayangnya, pendidikan di Indonesia masih kurang mengapresiasi hak-hak komunitas marjinal. Kaum marjinal masih sulit mengakses pendidikan yang bermutu. Pemerintah belum memberikan perhatian dan perlakuan khusus kepada kelompok anak jalanan, kelompok miskin, buruh, urban kota, dan masyarakat adat. Komunitas marjinal hendaknya diberikan layanan pendidikan secara khusus. Kelompok-kelompok masyarakat semacam itu tidak bisa dipaksakan mengikuti pendidikan formal. Di sinilah, perlu ada model yang secara khusus memberikan layanan pendidikan kepada mereka tanpa aturan-aturan yang kaku dan formal. Tak heran, jika model pendidikan alternatif banyak dikembangkan oleh publik, misalnya membina anak jalanan yang tidak sempat lagi bersekolah formal karena sebagian besar waktunya tersita mencari nafkah.

Pelajaran yang bisa ditarik dari persolaan ini adalah bagaimana komitmen negara terhadap komunitas marjinal. Kepada siapa sesungguhnya pendidikan kita berpihak? Apakah negara sudah sungguh-sungguh mengamalkan amanat UUD 1945 untuk mencerdaskan kehidupan bangsa? Mengapa ada kesenjangan yang luar biasa dalam pendidikan "orang kaya" dengan pendidikan yang dihuni kaum marjinal? Bukankah dengan membiarkan kesenjangan itu terus berlangsung, sama dengan membenarkan tesisnya Samuel Bowles dan Herbert Gintis dalam Schooling in Capitalist 
America (1976), bahwa sekolah hanya berfungsi sebagai alat untuk melayani kepentingan masyarakat dominan dalam rangka mempertahankan dan mereproduksi status quo? Karena itulah, komunitas marjinal harus diyakinkan bahwa mereka berhak dan mampu menentukan nasib sendiri, berhak mendapatkan keadilan, berhak melawan segala bentuk diskriminasi dalam pendidikan. Pendidikan kita sudah seharusnya berpihak kepada mereka, bukan mengabdi kepentingan masyarakat dominan.

Dalam bentuk apa pun, komunitas marjinal seharusnya mendapat akses pendidikan sehingga mereka bisa mendapat akses yang sama terhadap sumber daya. Karena sesungguhnya mereka adalah manusia yang memiliki hak yang sama dalam meraih kesempatan. Bahwa manusia dilahirkan dengan bahasa tertentu, dengan jenis kelamin tertentu, di daerah tertentu, dengan bahasa tertentu, bahkan agama tertentu bukanlah menjadi hambatan bahwa orang bersangkutan tidak lebih berharga dari lainnya. Tapi mengapa muncul diskriminasi, pengucilan, tindakan segregatif, dan sejenisnya pada kelompok tertentu?

Bahkan dalam beberapa hal diperlukan kebijakan afirmasi untuk mendukung kelompok ini agar memiliki ruang dan kesempatan yang sama dalam akses pendidikan. Kebijakan afirmasi ini penting untuk mempromosikan kesempatan yang sama pada kelompok tidak beruntung, baik secara ekonomi, sosial, budaya, dan semacamnya. Dengan kebijakan afirmatif kita bisa memaksimalkan manfaat kemajemukan di seluruh level masyarakat dan memperbaiki keadaan yang merugikan karena diskriminasi. Ini artinya bahwa kebijakan afirmatif ini memiliki justifikasi, yaitu menolong diskriminasi dan ketidaksetaraan serta mempromosikan keterbukaan. Dengan cara ini, setidaknya kesenjangan akibat tidak seimbangnya akses perlahan bisa dihindari.

Sebagai bagian integral dari sistem pendidikan nasional sesuai dengan UU No. 20/2003 tentang Sistem Pendidikan Nasional, pendidikan madrasah di bawah pembinaan Kementerian Agama memiliki peran yang sangat besar dalam upaya pencerdasan bagi seluruh warganegara. Pendidikan madrasah memberikan kesempatan yang seluas-luasnya bagi seluruh warga negara untuk 
mengaksesnya tanpa adanya perbedaan status sosial. Di masa lalu dan juga terjadi di masa sekarang, madrasah, memiliki peran yang signifikan dalam memberikan akses kepada komunitas marjinal. Karena pendidikan madrasah tidak diorientasikan pada kelompok sosial masyarakat tertentu saja. Pendidikan madrasah sangat terbuka terhadap seluruh kelompok sosial masyarakat. Dalam konteks inilah, pencarian pengembangan madrasah di komunitas marjinal sangat diperlukan dalam kerangka yang lebih luas untuk menemukan model pengembangan madrasah. Papua yang terus mengalami pergolakan terkait disintegrasi bangsa, memiliki ragam komunitas, etnik, dan agama. Tanah Papua yang mayoritas masyarakat hidup dalam kemiskinan dan keterbelakangan selayaknya mendapatkan afirmatif action dalam pengembangan pendidikan termasuk pendidikan madrasah. Mencermati pendidikan madrasah di Papua, khususnya Kota Jayapura penting dalam mengungkap pengalaman dan problem empirik pengembangan pendidikan madrasah dalam rangka menemukan model pengembangan pendidikan madrasah di tanah Papua tersebut.

\section{KONDISI KOTA JAYAPURA}

\section{A. Geo-Demografis}

Kota Jayapura yang luasnya $940 \mathrm{~km} 2$ secara geografis terletak diantara $130^{\circ}-141^{\circ}$ bujur timur dan dan $1^{\circ} 27^{\prime}-3^{\circ} 49$ lintang selatan. Batas wilayahnya, sebelah utara, berbatasan dengan Samudera Pasifik, sebelah selatan, berbatasan dengan Distrik Arso Kabupaten Kerom. Sebelah timur berbatasan dengan Papua New Guinea, dan sebelah Barat, berbatasan dengan Distrik Depapare Kabupaten Jayapura. Wilayah Kota Jayapura meliputi 5 Kecamatan yaitu Kecamatan Abepura $\left(155,7 \mathrm{~km}^{2}\right)$, Jayapura Selatan $\left(43,4 \mathrm{~km}^{2}\right)$, Jayapura Utara $\left(51 \mathrm{~km}^{2}\right)$, Muara Tami $(626,7$ $\left.\mathrm{km}^{2}\right)$, dan Kecamatan Heram $\left(63,2 \mathrm{~km}^{2}\right)$. Menurut data pada tahun 2007 penduduk Kota Jayapura berjumlah 230.824 jiwa, dan penduduk terbanyak berada di distrik Jayapura Utara, kemudian Jaya pura Selatan, Abepura, Heram dan Muara Tami. Untuk luas wilayah dan kepadatan penduduk dapat dilihat pada tabel berikut: 
Tabel 1.

Luas Wilayah Kecamatan dan Kepadatan Penduduk Tahun 2004

\begin{tabular}{|c|r|c|r|}
\hline Kecamatan & \multicolumn{1}{|c|}{$\begin{array}{c}\text { Luas } \\
\text { (Km2 }\end{array}$} & $\begin{array}{c}\text { Jumlah } \\
\text { Penduduk/ }\end{array}$ & $\begin{array}{c}\text { Kepadatan } \\
\text { Penduduk/km2 }\end{array}$ \\
\hline (1) & $(2)$ & $(3)$ & $(4)$ \\
\hline 1. Abepura & 155,7 & 60.430 & 388 \\
\hline 2. Jayapura Selatan & 43,4 & 61.403 & 1.414 \\
\hline 3. Jayapura Utara & 51 & 63.431 & 1.243 \\
\hline 4. Muara Tami & 626,7 & 11.585 & 19 \\
\hline 5. Heram & 63,2 & 33.875 & 536 \\
\hline Kota Jayapura & 940 & 230.824 & 245 \\
\hline
\end{tabular}

Sumber: BPS Kota Jayapura, 2005.

Jumlah penduduk di suatu daerah sebenarnya merupakan aset dan potensi pembangunan yang besar, manakala penduduk tersebut berkualitas. Sebaliknya dengan jumlah dan pertumbuhan penduduk yang pesat tetapi dengan kualitas yang rendah akan menjadi beban besar bagi proses pembangunan. Jumlah penduduk Kota Jayapura tahun 2004 berdasarkan tabel tercatat 230.824 jiwa dengan jumlah kepadatan penduduk 245 dan jumlah penduduk laki-laki 122.485 dan perempuan 108.339 dengan sex rasio sebesar 113 artinya setiap 100 penduduk perempuan terdapat 113 penduduk laki- laki .

Tabel 2.

Penduduk Kota Jayapura Menurut Umur dan Jenis kelamin Tahun 2007

\begin{tabular}{|r|r|r|r|}
\hline Kelompok Umur & \multicolumn{1}{c|}{ Laki-laki } & \multicolumn{1}{c|}{ Perempuan } & \multicolumn{1}{c|}{ Jumlah } \\
\hline$[1]$ & \multicolumn{1}{|c|}{$[2]$} & {$[3]$} & {$[4]$} \\
\hline $0-4$ & 12.486 & 10.995 & 23.481 \\
\hline $5-9$ & 13.985 & 11.701 & 25.686 \\
\hline $10-14$ & 11.368 & 8.735 & 20.103 \\
\hline $15-19$ & 13.184 & 11.328 & 24.512 \\
\hline
\end{tabular}




\begin{tabular}{|r|r|r|r|}
\hline $20-24$ & 9.344 & 10.453 & 19.797 \\
\hline $25-29$ & 10.938 & 12.094 & 23.032 \\
\hline $30-34$ & 10.195 & 10.282 & 20.477 \\
\hline $35-39$ & 9.879 & 10.023 & 19.902 \\
\hline $40-44$ & 9.513 & 8.496 & 18.009 \\
\hline $45-49$ & 6.651 & 4.899 & 11.550 \\
\hline $50-54$ & 6.306 & 3.991 & 10.297 \\
\hline $55-59$ & 4.215 & 2.463 & 6.678 \\
\hline $60-64$ & 1.945 & 1.262 & 3.207 \\
\hline $65+$ & 2.314 & 1.779 & 4.093 \\
\hline Total th 2007 & 122.485 & 108.339 & 230.824 \\
\hline Th. 2006 & 116.216 & 101.811 & 218.027 \\
\hline
\end{tabular}

Sumber: BPS Kota Jayapura

Pertumbuhan penduduk di Kota Jayapura tidak hanya disebabkan oleh pertumbuhan secara alamiah, tetapi tidak lepas karena pengaruh migran yang masuk yang disebabkan daya tarik Kota Jayapura dengan berkembangnya potensi Industri, perdagangan dan jasa sehingga mengakibatkan tersedianya lapangan kerja dan kondusifnya kesempatan berusaha.

Disamping itu sebagai daerah yang berbatasan dengan Negara Papua New Guinea mau tidak mau harus menampung pula pendatang tamu dari negara tersebut yang melakukan aktifitas ekonomi kesehariannya di wilayah perbatasan dengan Jayapura.

Persebaran atau distribusi penduduk pada dasarnya merupakan komposisi penduduk berdasarkan geografis, akan lebih bermakna apabila dikaitkan dengan kepadatan. Dari data persebaran penduduk dapat dilihat diwilayah mana terjadi pemusatan penduduk. Jayapura Selatan dan Jayapura Utara boleh dikatakan daerah cukup padat, tiap kilometer persegi rata-rata dihuni lebih kurang 1.200 jiwa, Dimana Kecamatan Jayapura Selatan merupakan Kecamatan dengan kepadatan tertinggi (1.412 
jiwa/ km2), sementara Kecamatan Muara Tami dengan luas 626,7 $\mathrm{Km} 2$ dengan jumlah penduduk 11.685 jiwa sehingga kepadatan penduduknya terendah adalah di Kecamatan Muara Tami yaitu 19 jiwa $/ \mathrm{km} 2$.

Tabel 3.

Penduduk Kota Jayapura umur 15 tahun keatas menurut pendidikan tertinggi yang ditamatkan

\begin{tabular}{c|lcr}
\hline No. & Pendidikan yang ditamatkan & Jumlah & \multicolumn{2}{l}{ Persentase } \\
\hline (1) & \multicolumn{1}{c}{$(2)$} & $(3)$ & $(4)$ \\
1. & Tidak/ belum tamat SD & 10.582 & 6,55 \\
2. & Sekolah Dasar & 24.766 & 15,33 \\
3. & SMP & 31.684 & 19,59 \\
4. & SMU & 50.211 & 31,08 \\
5. & SM Kejuruan & 17.060 & 10,56 \\
6. & Diploma I/II & 1.373 & 0,85 \\
7. & Diploma III & 5,961 & 3,69 \\
8. & Universitas/Diploma IV & 18.304 & 11,33 \\
9. & S2-S3 & 1.648 & 1,02 \\
\hline
\end{tabular}

\section{B. Keagamaan}

Pemeluk agama terbesar di Kota Jayapura berdasarkan data Badan Statistik Kota Jaya pura tahun 2005 adalah Protestan, kemudian diikuti oleh Pemeluk Islam dan ketiga adalah pemeluk Katholik.

Tabel 4.

Jumlah Penduduk Menurut Agama Perkecamatan Tahun 2005

\begin{tabular}{|l|l|l|l|l|l|l|l|}
\hline No & Kecamatan & \multicolumn{6}{|c|}{ Agama } \\
\cline { 3 - 8 } & & Islam & Protestan & Katholik & Hindu & Budha & Jumlah \\
\hline 1 & Abepura & 33.825 & 30.421 & 11.415 & 1.109 & 530 & 77.310 \\
\hline 2. & $\begin{array}{l}\text { Jayapura } \\
\text { Selatan }\end{array}$ & 29.793 & 34.616 & 12.626 & 690 & 478 & 78.203 \\
\hline 3. & $\begin{array}{l}\text { Jayapura } \\
\text { Utara }\end{array}$ & 19.546 & 24.154 & 6.770 & 69 & 51 & 50.587 \\
\hline 4. & $\begin{array}{l}\text { Muara } \\
\text { Tami }\end{array}$ & 3.214 & 1.124 & 1.400 & 10 & 1 & 5.740 \\
\hline & Th 2005 & 86.378 & 90.325 & 32.211 & 1.878 & 1.060 & 211.849 \\
\hline & Th 2004 & 87.540 & 94.490 & 41.312 & 2.489 & 1.816 & 227.647 \\
\hline
\end{tabular}


Untuk melihat jumlah sarana ibadah perkecamatan yang ada di Kota Jayapura dapat dilihat pada tabel berikut :

Tabel 5.

Jumlah Sarana Ibadah Di Kota Jayapura Tahun 2007

\begin{tabular}{|l|c|c|c|c|c|c|}
\hline Kecamatan & Mesjid & $\begin{array}{c}\text { Surau/ } \\
\text { langgar }\end{array}$ & $\begin{array}{c}\text { Gereja } \\
\text { Katolik }\end{array}$ & $\begin{array}{c}\text { Gereja } \\
\text { Protestan }\end{array}$ & Vihara & Pura \\
\hline$[1]$ & {$[2]$} & {$[3]$} & {$[4]$} & {$[5]$} & {$[6]$} & {$[7]$} \\
\hline 1. Abepura & 31 & 7 & 5 & 36 & - & \\
\hline 2. Jayapura Selatan & 26 & 9 & 5 & 52 & 2 & 1 \\
\hline 3. Jayapura Utara & 34 & 13 & 16 & 36 & - & - \\
\hline 4. Muara Tami & 8 & 1 & 4 & 8 & 16 & - \\
\hline Jumlah th 2005 & 99 & 30 & 30 & 140 & 2 & 1 \\
\hline Jumlah th 2004 & 104 & 30 & 28 & 135 & 1 & 1 \\
\hline
\end{tabular}

Sumber: Pemerintah Kota Jayapura 2007

Sekalipun pemeluk agama Islam menempati urutan nomor dua setelah Protestan pada tahun 2005, namun dilihat jumlah rumah ibadah yang ada pada tahun 2007 ternyata untuk umat Islam lebih besar dibandingkan dengan tempat ibadah agama lain. Dengan kondisi ini diperkirakan bahwa selama beberapa tahun terakhir pertambahan penduduk pendatang yang beragama Islam semakin banyak di Kota jayapura.

\section{GAMBARAN TENTANG PENDIDIKAN}

\section{A. Pendidikan Umum}

Pendidikan merupakan suatu faktor kebutuhan dasar untuk setiap manusia sehingga upaya mencerdaskan kehidupan bangsa melalui pendidikan merupakan bagian dari upaya peningkatan kesejahteraan rakyat. Jika pembangunan yang dilakükan tidak dapat mengandalkan sumber daya alam yang keberadaanya terbatas maka peningkatan sumber daya manusia yang hasilnya merupakan modal untuk penggerak pembangunan merupakan suatu keniscayaan. 
Pemerataan kesempatan pendidikan sangat dipengaruhi oleh tersedianya sarana dan prasarana pendidikan seperti gedung sekolah, perpustakaan, dan buku- buku penunjang pelajaran serta tenaga pendidik (guru). Fasilitas pendidikan di Kota Jayapura pada tahun 2007 tersedia mulai dari tingkat pendidikan dasar, lanjutan, menengah dan kejuruan di Kota Jayapura adalah sbb:

Tabel 6.

\begin{tabular}{l|llll}
\hline No. & Jenjang Pendidikan & Jm/ Sekolah & Jm/ Guru & Jml Murid \\
\hline \multirow{2}{1.}{} & TK & 45 & 2003 & 3.830 \\
2. & SD/MI/SLB & 90 & 1.380 & 31.232 \\
3. & SLTP/MTs & 36 & 806 & 12.415 \\
4. & SMU/MA & 9 & 490 & 3.800 \\
\multirow{2}{*}{ Jumlah } & Th 2007 & 203 & 3.545 & 59.237 \\
\cline { 2 - 5 } & Th 2006 & 198 & 3.562 & 52.357 \\
\hline
\end{tabular}

Sarana pendidikan tersebut dikelola oleh pihak pemerintah dan swasta baik yang bersifat umum maupun khusus. Salah satu pendidikan tinggi yang cukup terkenal di kota Jayapura adalah Universitas Cendrawasaih (UNCEN) .

\section{B. Pendidikan Madrasah}

Satuan pendidikan lainnya dibawah binaan Kementerian Agama seperti Madrasah Ibtidaiyah (MI), Madrasah Tsanawiyah (MTs), dan Madrasah Aliyah (MA) di Kota Jayapura pada tahun 2007/2008 adalah sbb:

Tabel 7.

\begin{tabular}{|l|l|l|l|l|l|l|l|}
\hline No. & Jenjang Madrasah & \multicolumn{2}{|c|}{ JIm Madrasah } & \multicolumn{2}{c|}{ Jml guru } & \multicolumn{2}{c|}{ Jml siswa } \\
\hline & & Negeri & Swasta & PNS & Hnr & Lk & Pr \\
\hline 1. & Madrasah Ibtidaiyah & - & 4 & 22 & 12 & 211 & 179 \\
\hline 2. & $\begin{array}{l}\text { Madrasah } \\
\text { Tsanawiyah }\end{array}$ & - & 6 & 6 & 81 & 186 & 165 \\
\hline 3. & Madrasah Aliyah & - & 3 & Td & td & 60 & 60 \\
\hline
\end{tabular}

$T d=$ Tidak ada data

Sampai saat ini madrasah yang ada di Kota Jayapura semuanya berstatus swasta untuk semua jenjang. Karena itu untuk pemerataan diperlukan adanya madrasah yang berstatus negeri untuk setiap jenjang, dengan demikian ada madrasah pembina/ contoh bagi madrasah swasta lainnya. 
Adapun angka pertisipasi murni (APM) dan partisipasi kasar (APK) pada sekolah dan madrasah di Kota Jayapura adalah sbb:

Tabel 8.

APM dan APK Sekolah dan Madrasah Kota Jayapura

\begin{tabular}{|c|c|c|c|c|c|c|}
\hline $\begin{array}{l}\text { Penduduk } \\
7-12 \text { th } \\
\end{array}$ & \multicolumn{5}{|c|}{$\begin{array}{l}\text { Murid usia } \\
7-12 \text { th }\end{array}$} & $\begin{array}{l}\mathrm{Iml} \\
\text { Murid SD/MI }\end{array}$ \\
\hline & SD/MI & \multicolumn{2}{|c|}{ SMP/MTs } & \multicolumn{2}{|l|}{$\mathrm{Jml}$} & \\
\hline 29.469 & 25.794 & \multicolumn{2}{|l|}{3.130} & \multicolumn{2}{|c|}{28.942} & 31.232 \\
\hline \multirow[t]{2}{*}{$\begin{array}{l}\text { Penduduk } \\
13-15 \text { Th }\end{array}$} & \multicolumn{5}{|c|}{ Murid Usia 13-15 } & $\begin{array}{l}\text { Murid SMP/ } \\
\text { MTs }\end{array}$ \\
\hline & $\begin{array}{l}\text { SD/ } \\
\mathrm{MI}\end{array}$ & $\begin{array}{l}\text { SMP/ } \\
\text { MTs }\end{array}$ & $\begin{array}{l}\text { SMA/ } \\
\text { MA }\end{array}$ & SMK & $\mathrm{JML}$ & \\
\hline \multirow[t]{2}{*}{12.466} & 1.154 & 8.680 & 1.725 & 261 & 11.840 & 12.415 \\
\hline & \multicolumn{5}{|c|}{ SMP/MTs/SMA/MA/SMK } & \\
\hline $\begin{array}{l}\text { Penduduk } \\
16-18 \text { th }\end{array}$ & \multicolumn{5}{|c|}{ Murid usia $16-18$ th } & $\begin{array}{l}\text { Jumlah murid SMA/ } \\
\text { SMK }\end{array}$ \\
\hline 10.804 & \multicolumn{5}{|l|}{9.352} & 11.760 \\
\hline
\end{tabular}

\begin{tabular}{|c|c|c|c|c|c|}
\hline \multirow{2}{*}{$\begin{array}{l}\text { Jml } \\
\text { Murid SD/Ml }\end{array}$} & \multicolumn{4}{|c|}{ APM (\%) } & \multirow[t]{2}{*}{ APK (\%) } \\
\hline & $\mathrm{SD} / \mathrm{MI}$ & \multicolumn{2}{|l|}{$\begin{array}{l}\text { SMP/ } \\
\text { MTs }\end{array}$} & $\mathrm{JmI}$ & \\
\hline 31.232 & 87.53 & \multicolumn{2}{|l|}{10.62} & 98.15 & 105.98 \\
\hline $\begin{array}{l}\text { Murid SMP/ } \\
\text { MTs }\end{array}$ & \multicolumn{4}{|l|}{ APM } & APK \\
\hline & $\begin{array}{l}\mathrm{SD} / \\
\mathrm{MI}\end{array}$ & SMP/MTS & SLTA & $\mathrm{JML}$ & \\
\hline \multirow[t]{2}{*}{12.415} & 9.26 & 69.63 & 16.09 & 94.98 & 99.59 \\
\hline & \multicolumn{4}{|c|}{ SMA/MA/SMK } & \\
\hline $\begin{array}{l}\text { Jumlah murid SMA/ } \\
\text { SMK }\end{array}$ & \multicolumn{4}{|l|}{ Apm } & Apk \\
\hline 11.760 & \multicolumn{4}{|l|}{86,56} & 108,85 \\
\hline
\end{tabular}

\section{Pendidikan Madrasah di Kota Jayapura}

Kota Jayapura memiliki 6 Madrasah Ibtidaiyah (MI), 8 Madrasah Tsanawiyah (MTs), dan 4 Madrasah Aliyah (MA) yang semuanya berstatus swasta. Tahun pelajaran 2008/2009 jumlah siswa terbanyak untuk jenjang MI sebesar 271 siswa pada MI AlMa'arif Numbay Abepura Jayapura dan jumlah siswa terkecil sebanyak 31 di MI Koya Barat Kota Jayapura. Pada MTs jumlah siswa terbanyak dari kelas 7-9 adalah 81 siswa di MTs DDI-AD 
Entrop Kota Jayapura dan jumlah siswa MTs paling sedikit pada MTs Al-Hidayah Abepura Jayapura sebanyak 12 siswa, sedangkan jenjang MA jumlah siswa terbanyak di MA DDI-AD Entrop sebanyak 41, jumlah siswa terkecil pada MA YAPNI Koya Timur Distrik Muara Tami sejumlah 24 siswa (dihimpun dari data Madrasah Kanwil Kementerian Agama Propinsi Papua).

Madrasah di Propinsi Papua tergolong sangat kecil bila dibandingkan dengan jumlah madrasah pada daerah lain seperti di wilayah Sumatera, Kalimantan, maupun Sulawesi. Jumlah madrasah perkabupaten adalah : Kota Jayapura 6 MI, 8 MTs, dan 4 MA. Kabupaten Jayapura 4 MI, 2 MTs, dan 3 MA. Kabupaten Keerom 4 MI, 3 MTs, dan 1 MA. Kabupaten Merauke 4 MI, 6 MTs, dan 4 MA. Kabupaten Nabire 3 MI, 2 MTs, dan 2 MA. Kabupaten Yapen Waropen 1 MI, 1 MTs, dan 0 MA. Kabupaten Biak Numfor 1 MI, 1 MTs, dan 0 MA. Kabupaten Mimika 1 MI, 1 MTs, dan 0 MA. Kabupaten Jayawijaya 1 MI, 0 MTs, dan 0 MA, sedangkan Kabupaten Sarmi 0 MI, 1 MTs, dan 0 MA.

\section{Pandangan Pemda terhadap Madrasah}

Anggaran pemda yang diperuntukkan khusus pengembangan madrasah tidak muncul di dalam Anggaran Penerimaan dan Belanja Daerah (APBD) Kota Jayapura. Anggaran pemda kota Jayapura yang peruntukkannya pengembangan kegiatan keagamaan muncul dalam program pemberdayaan kelembagaan kesejahteraan sosial yang dikelola dinas sosial Kota Jayapura. Anggaran sosial tersebut meliputi, program peningkatan kualitas kerukunan umat beragama sebesar 1,2 milyar dana ini bersumber dari Dana Alokasi Umum (DAU) yang diharapkan keluarannya adalah meningkatnya kepedulian tokoh agama dan hasilnya adalah terbinanya kerukunan antar umat beragama. Justru di dalam APBD muncul program bantuan dana penunjang pendidikan bagi mahasiswa asli Port Numbay dan umum sebesar 550 juta rupiah yang bersumber dari dana otonomi khusus (otsus) yang peruntukkannya adalah bantuan pendidikan mahasiswa.

Anggaran lain terkait pembinaan keagamaan adalah program peningkatan pembinaan kerukunan umat beragama sebesar $\mathbf{8 5 0}$ juta rupiah. Program lainnya adalah peningkatan sarana dan 
prasarana keagamaan sebesar 850 juta, program ini diarahkan untuk pemenuhan fasilitas pelayanan keagamaan. Menurut Wakil Walikota Sudjarwo alokasi dana untuk pengembangan program keagamaan yang dikelola dinas sosial penggunaannya dilakukan bersama Kementerian Agama kota Jayapura, sejalan dengan hal tersebut anggota DPRD kota Jayapura dari fraksi PKS bapak Ahmad Jaenuri, LC mengatakan bahwa anggaran kegiatan keagamaan dikelola Dinas Sosial karena kekhawatiran terhadap Peraturan Menteri Dalam Negeri Nomor 59 tahun 2007 tentang Perubahan atas Peraturan Menteri Dalam Negeri Nomor 13 tahun 2006 tentang Pedoman Pengelolaan Keuangan Daerah, dimana pengelolaan APBD tidak dibenarkan dikelola oleh unit instansi vertikal seperti Kementerian Agama.

\section{E. Penyelenggaraan Madrasah}

Beberapa madrasah di kota Jayapura melaksanakan program pembelajaran dengan baik walaupun terbatas dalam hal pengembangan, salah satunya karena keterbatasan anggaran, sedangkan bantuan dari pemerintah daerah kota Jayapura praktis tidak ada. Sebagai contoh keadaan beberapa madrasah di kota Jayapura.

\section{MI Nurul Huda YAPIS}

MI Nurul Huda YAPIS berstatus swasta, beralamat di jalan Percetakan Negara nomor 126 Jayapura. Madrasah ini memiliki jenjang akreditasi disamakan, lembaga didirikan tahun 1968 merupakan yayasan lembaga pendidikan al-Ma'arif. Bangunan MI berdiri diatas bangunan ukuran 1400 meter persegi. Madrasah telah melakukan beberapa kali renovasi dan rehabilitasi beberapa kali, melalui bantuan dari pemerintah, Dinas Pendidikan dan Pengajaran, Kementerian Agama, dan bantuan masyarakat muslim umumnya di kota Jayapura sehingga sekolah ini berlantai 3 .

Data guru madrasah menunjukkan 8 orang guru berasal dari Kementerian Agama dan Dinas Pendidikan, guru tetap yayasan sebanyak 1 dan guru tidk tetap 4 orang ditambah seorang kepala madrasah. Jumlah siswa pada tahun pelajaran 2008/2009 sebanyak 184 siswa. Madrasah ini memiliki meubelair dan barang 
ruang kelas yang cukup memadai, perabot kantor lengkap ditambah perabot perpustakaan, UKS, dan alat peraga.

Permasalahan yang dihadapi MI Nurul Huda YAPIS adalah keterbatasan sarana prasarana laboratorium dan kantin. Aspek lainnya masih minimnya partisipasi orang tua siswa dalam program pengembangan madrasah, selain itu minat siswa dalam pengembangan akademik masih rendah.

\section{MTs Darul Ma'arif Numbay}

MTs Darul Ma'arif terakreditasi B, berdiri sejak tahun 2002. Madrasah ini memiliki beberapa prestasi antara lain, juara II cipta karya puisi tingkat kota Jayapura tahun 2009 , finalis cerdas cermat fisika tahun 2009 tingkat kota Jayapura, dan finalis olimpiade matematika tingkat kota Jayapura.

Kondisi bangunan madrasah sederhana dan memerlukan renovasi pada beberapa bagiannya. Madrasah ini memiliki 3 ruang kelas dan 1 ruang perpustakaan. Jumlah guru sebanyak 14 ditambah seorang staf Tata Usaha. Sedangkan jumlah siswa pada tahun pelajaran 2008/2009 sebanyak 71 siswa.

\section{MA Darud Da'wah wal Irsyad (DDI) Jayapura}

Madrasah DDI berstatus swasta dibawah yayasan pondok pesantren DDI kota Jayapura. MA ini memiliki siswa pada tahun pelajaran 2008/2009 sebesar 43 siswa terdiri dari 12 siswa kelas X, 12 siswa kelas XI, dan 19 siswa kelas XII. MA memiliki 5 orang guru PNS dari Kementerian Agama dan dinas pendidikan, 6 guru GTT, dan 6 GTY berkualifikasi S1, sedangkan seorang guru berkualifikasi D2.

Sarana prasarana yang dimiliki terbatas, tidak ada laboratorium IPA maupun laboratorium komputer, namun terdapat laboratorium bahasa yang keadaannya cukup baik. Jumlah kelas sebanyak 3 ruang, dilihat dari keadaan siswa, sebagian besar orangtua siswa telah berpendidikan perguruan tinggi, dan sebagian besar bekerja sebagai karyawan swasta. Biaya operasional sekolah bersumber dari orang tua siswa, yayasan, maupun donatur lainnya. Penyelenggaraan pembelajaran madrasah 
dilakukan secara mandiri oleh lembaga pendidikan dan kurang mendapatkan perhatian dari Kementerian Agama apalagi pemda.

\section{F. Hubungan Pemerintah Daerah, Kementerian Agama, dan Madrasah dalam Penyelenggaraan Pendidikan di Madrasah}

Kondisi madrasah di Jayapura belum mampu bersaing dengan persekolahan yang dikelola dinas Pendidikan. Menurut Andi (Kabag TU kanwil Kementerian Agama) tidak diperkenankan adanya aliran dana ke madrasah oleh pemerintah kota Jayapura, hal ini dapat dilihat dari APBD kota Jayapura. Terdapat fenomena kepindahan pegawai Kementerian Agama ke pemda akibat timpangnya kesejahteraan pegawai dibawah instansi vertikal (Kementerian Agama) dibandingkan pegawai pemda. Tunjangan kerja tidak ada bagi pegawai dibawah naungan Kementerian Agama, uang makan 25 ribu untuk pegawai pemda, dan 15 ribu untuk pegawai Kementerian Agama sehingga banyak pegawai Kementerian Agama yang berpindah ke pemda.

Komposisi DPRD kota Jayapura terdapat beberapa legislator beragama Islam, namun untuk mendorong program terkait pengembangan madrasah mengalami kesulitan baik secara politik maupun administratif. Data statistik menunjukkan jumlah penduduk beragama Islam berimbang dengan pemeluk agama lainnya, namun pemerintah daerah belum banyak memperhatikan pengembangan program keagamaan secara merata bagi pemeluk agama Islam di kota Jayapura.

Pemda kota Jayapura tidak melakukan pembinaan terhadap madrasah. Dana Alokasi Khusus (DAK) tidak terdistribusi untuk madrasah, peruntukkannya hanya untuk sekolah sehingga program pengembangan sarana bagi pendidikan dasar di madrasah banyak terhambat. Lain halnya dengan keberadaan guru di madrasah beberapa berasal dari dinas pendidikan, hal ini menunjang pembelajaran di madrasah, seperti halnya pada MI Miftahul Hak di kota Jayapura. Dinas sosial kota Jayapura memberikan pelatihan bagi guru agama dalam program-program keagamaan dan peningkatan kualitas pendidik di madrasah, namun menurut guru-guru di madrasah pelatihan yang dikelola 
dinas sosial belum menemui sasaran sebagaimana yang dilakukan Kementerian Agama.

Kondisi sarana-prasarana dan fasilitas belajar di madrasah sangat kurang dibandingkan fasilitas sekolah, termasuk bukubuku pelajaran agama dan lain-lain. Terdapat resistensi masyarakat terhadap madrasah, seperti halnya kasus di distrik 9 Jayapura perkembangan Playgroup menjadi TK yang dikelola yayasan muslimat NU diisukan sebagai bentuk Islamisasi sehingga masyarakat menuntut lembaga tersebut dibubarkan, hal ini menunjukkan kondisi sosial masyarakat Jayapura masih cukup antipati terhadap keberadaan lembaga pendidikan agama termasuk madrasah.

Langkah-langkah yang dilakukan Kementerian Agama adalah upaya menegerikan madrasah, hal ini dimaksudkan untuk memperkuat pengembangan madrasah khususnya pada daerahdaaerah basis dakwah Islam. Menurut Ahmad Jaenuri anggota DPRD kota Jayapura, perkembangan agama Islam dan lembaga pendidikannya berkembang signifikan. Hal ini akibat dari migrasi masyarakat Islam yang masuk ke papua. Cerminan cukup besarnya masyarakat Islam di papua terlihat dari komposisi anggota DPRD kota Jayapura, sebanyak 9 orang dari total 30 anggota DPRD kota Jayapura beragama Islam.

Bentuk perjuangan anggota DPRD Jayapura dalam program pengembangan kegiatan keagamaan Islam misalnya, bantuan 2 milyar untuk kegiatan MTQ pada tahun 2007. Setiap tahun terdapat bantuan dana untuk MTQ sebesar 1 milyar, selain itu terdapat bantuan untuk dewan masjid, dan TPA/TPQ mendapatkan bantuan 1-2 juta bahkan ada yang mendapatkan bantuan 3 juta setiap tahunnya dari pemda kota Jayapura.

Kegiatan-kegiatan keagamaan yang semula dikelola Kementerian Agama dialihkan pada dinas sosial akibat dari surat edaran Mendagri, DPRD mendorong adanya kegiatan bersama dinas sosial dan Kementerian Agama kota Jayapura. Kepedulian pemerintah kota Jayapura terhadap kegiatan keagamaan cukup tinggi termasuk kegiatan bagi agama Islam, sebagai contoh : visi kota Jayapura sebagai kota beriman diwujudkan dengan menempatkan 
masalah keagamaan pada nomor satu diimbangi dengan anggaran yang memadai, kegiatan safari ramadhan dilakukan dengan wali kota (pemda) dengan turun ke masjid-masjid dengan memberikan bantuan langsung pada masjid-masjid di bulan ramadhan. Sedangkan untuk pendidikan agama pemda memberikan bantuan berupa alat-alat pendidikan agama (rebana, mukenah dll), selain itu pemda juga memberikan bantuan untuk kegiatan Dewan Masjid sebesar 50 juta, dan BAZDA sebanyak 50 juta rupiah.

APBD kota Jayapura pada tahun 2009 sebesar 598 milyar. Jumlah penduduk beragama Islam sebanyak 230 ribu jiwa atau $40 \%$ dari jumlah masyarakat kota Jayapura. Anggaran APBD kota Jayapura semestinya mampu diarahkan pada pengembangan berbagai sektor pembangunan termasuk pendidikan (agama). Menurut Jaenuri lembaga pendidikan madrasah di kalangan masyarakat Jayapura belum familier, hal tersebut terlihat dari animo masyarakat dalam menyekolahkaan anaknya di madrasah. Tantangan berat bagi pengembangan madrasah adalah memperkenalkan madrasah pada masyarakat Islam di kota Jayapura.

Menurut Jaenuri, posisi madrasah di kota Jayapura masih berat, sehingga pemerintah pusat diharapkan menangani dan memberikan perlakuan khusus pada madrasah di kota Jayapura yang sedang berkembang ini. Aspek lain yang menjadikan madrasah kurang mendapatkan perhatian dari pemda adalah situasi politik dimana daya tawar kelompok muslim yang masih rendah di Jayapura sehingga pemanfaatan dana APBD apalagi dana otonomi khusus untuk pengembangan kegiatan keagamaan Islam termasuk madrasah terkendala.

Pelaksanaan kegiatan pembelajaran di madrasah selama ini telah berjalan walaupun belum mengalami perkembangan yang signifikan (menurut Irawaty, kepala madrasah Darul Maarif). Sedangkan kepala MI Nurul Huda Yappis mengatakan, pada tahun 2007 terdapat bantuan untuk MI Nurul Huda Yappis sebesar 93,5 juta melalui dinas pendidikan dan pengajaran propinsi Papua yang peruntukkannya adalah penambahan ruang kelas baru sebanyak 2 ruang. Untuk mendapatkan bantuan tersebut madrasah melakukan pendekatan pribadi (loby) kepala madrasah pada 
dinas pendidikan yang secara kebetulan suaminya bekerja di dinas pendidikan dan pengajaran propinsi Papua.

Menurut kepala MA DDI, pemda dalam beberapa hal telah memberikan bantuan berupa buku pelajaran KTSP, beasiswa untuk siswa sebanyak 9 siswa masing-masing 65 ribu perbulan selama setahun, bantuan tenaga guru sebanyak 3 orang dari pemda berstatus honorer sebagai guru umum bahasa inggris dan kimia. Sedangkan MTs mendapatkan bantuan dari pemda berupa Bantuan Operasional Pendidikan (BOP) 500 ribu perbulan, buku pegangan guru, pelatihan-pelatihan dalam kegiatan KKG dan MGMP. Harapan para kepala madrasah adalah terjalinnya kerjasama pemda melalui dinas pendidikan dan Kementerian Agama sehingga pengelolaan pendidikan di madrasah lebih terarah.

Pandangan Wakil Walikota Jayapura, Sudjarwo, pemda sebenarnya konsen pada kegiatan-kegiatan keagamaan termasuk kegiatan masyarakat Islam. Namun pemda mengalami kesulitan dalam memberikan bantuan bagi madrasah yang dikelola instansi vertikal karena aturan Depdagri yang tidak memperbolehkan memberikan bantuan bagi unit dibawah instansi vertikal. Menurut Soedjarwo, sebelum ada aturan Depdagri bantuan keagamaan dikelola Kementerian Agama kota Jayapura, namun setelah ada aturan tersebut dialihkan pada Dinas Sosial kota Jayapura. Pemda pernah memberikan bantuan gedung pada MTs Hidayatullah. Peraturan Daerah (Perda) kota Jayapura berupa Perda Otsus memberikan prioritas pada aspek pendidikan, namun selama ini hubungan Kementerian Agama dan pemda sangat kurang.

Sejalan dengan pernyataaan wakil walikota, Kepala Dinas Pendidikan Kota Jayapura, Henky Pahabeherot menyatakan koordinasi dinas pendidikan dan Kantor Kementerian Agama Kota sangat rendah, namun dinas telah memberikan bantuan berupa tenaga guru di madrasah, yaitu madrasah dibawah yayasan pendidikan bahkan pihak yayasan menerima dana otsus. Dana DAK juga pernah diterimakan oleh dinas pendidikan pada Nurul Huda. Saran kepala dinas pendidikan adalah, Kementerian Agama melakukan kajian mendalam tentang pengembangan madrasah melalui kerjasama pemda maupun dinas pendidikan dengan 
anggaran otsus maupun APBD kota Jayapura. Senada dengan Ka Dinas Pendidikan, disampaikan oleh CH. Anwar al-Ma'mun, Kabid SMK, bahwa pemda memang tidak memberikan bantuan saranaprasarana, namun pemda memberikan bantuan berupa pelatihan guru.

Fenomena yang sangat merugikan bagi pencitraan dan pengembangan madrasah di kota Jayapura adalah terdapat MA yang memiliki tingkat kelulusan Ujian Nasional 0\%. Sedangkan menurut Made dari Kementerian Agama Kota Jayapura, bahwa kegiatan keagamaan oleh Depsos tidak profesional dan keluar sasaran. Kementerian Agama Kota Jayapura tidak pernah diajak dalam pembahasan anggaran tersebut, namun Kementerian Agama kota akan mengajak kerjasama program dengan dinas pendidikan dalam rangka pengembangan pendidikan termasuk madrasah di kota Jayapura.

\section{DESAIN PENDIDIKAN MADRASAH DI TANAH PAPUA}

Salah satu ragam perbedaan yang mendasar dalam pendidikan di Indonesia adalah aspek perbedaan status sosial; masyarakat miskin dan kelas menengah atas. Di sinilah peran pendidikan harus mampu memberikan dan mengakomodir warganegara yang berbeda status sosial untuk mendapatkan hak-hak pendidikan yang berkualitas. Karena tidak beralasan jika pendidikan hanya diorientasikan pada pemenuhan hak-hak warganegara tertentu.

Prinsipnya bahwa semua warga Negara memiliki hak yang sama untuk memenuhi kebutuhannya. Dari situlah, setidaknya ada empat prinsip utama yang harus menjadi pegangan agar semua warga Negara, dari kelompok manapun ia berasal, mampu menggapai hak-hak mereka sebagai warga Negara. Prinsip-prinsip tersebut yaitu: (1) keberpihakan pada komunitas marjinal; (2) aksi afirmatif (affirmative action); (3) keadilan distributif; (4) partisipasi yang setara (equal participation). 
Sayangnya, pendidikan di Indonesia masih kurang mengapresiasi hak-hak komunitas marjinal. ${ }^{1}$ Komunitas marjinal itu bisa diidentifikasi berdasarkan banyak hal, baik berdasarkan agama, etnik, gender, akses dan sebagainya. Tapi, pada umumnya pengkategorian dan pendefinisian komunitas marjinal ini digunakan untuk mengambarkan dan menganalisa sebuah situasi sosio-kultural, politik, dan ekonomi dimana masyarakat yang tidak beruntung daya dan untuk berpartisipasi penuh dalam kehidupan sosial.

Diperlukan kebijakan afirmasi untuk mendukung komunitas ini agar memiliki ruang dan kesempatan yang sama dalam akses pendidikan. Kebijakan afirmasi ini penting untuk mempromosikan kesempatan yang sama pada komunitas tidak beruntung, baik secara ekonomi, sosial, budaya, dan semacamnya. Dengan kebijakan afirmatif kita bisa memaksimalkan manfaat kemajemukan di seluruh level masyarakat dan memperbaiki keadaan yang merugikan karena diskriminasi. Ini artinya bahwa kebijakan afirmatif ini memiliki justifikasi, yaitu menolong diskriminasi dan ketidaksetaraan serta mempromosikan keterbukaan. ${ }^{2}$ Dengan cara ini, setidaknya kesenjangan akibat tidak seimbangnya akses perlahan bisa dihindari.

\section{A. Madrasah di Komunitas Marjinal}

Madrasah, sebagaimana tertuang dalam pasal 17 (2) Undangundang No. 20/2003 tentang Sistem Pendidikan Nasional merupakan bagian yang tak terpisahkan dari Undang Undang Sistem Pendidikan Nasional. Hal itu sejalan dengan tujuan Pendidikan Nasional yang mempunyai fungsi yang sama dengan satuan pendidikan lainnya terutama dalam mengembangkan kemampuan dan membentuk watak serta peradaban bangsa, bertujuan untuk berkembangnya potensi peserta didik agar menjadi manusia yang beriman dan bertakwa kepada Tuhan Yang Maha Esa, berakhlak

${ }^{1}$ Baca Mark Daniel dan Fletcher Linder, "Marginal People", dalam http://www.answers.com/topic/marginal-people. Diakses terakhir 5 Januari 2009.

'Laurence Sullivan, "Affirmative Action and Otsus", lihat www.papuaweb.org/dlib/lap/sullivan/en/affirmative.rtf 
mulia, sehat, berilmu, cakap, kreatif, mandiri, dan menjadi warga negara yang demokratis serta bertanggung jawab.

Di daerah marjinal, pengembangan madrasah diorientasikan pada pemberdayaan diri (self empowerment) dan pelibatan masyarakat (people engagement). Terkait dengan kebijakan desentralisasi pendidikan, maka pendidikan madrasah di komunitas marjinal diorientasikan pada usaha melembagakan pola pengelolaan pendidikan formal berbasis sekolah (school based management) dan menggalakkan partisipasi masyarakat sebagai kondisi untuk menciptakan pendidikan berbasis masyarakat (community based education). Pola pendekatan ini menekankan pengembangan madrasah pada pemberdayaan diri (SDM, manajemen, kurikulum, dan jaringan) dan pelibatan masyarakat secara luas.

Pemberdayaan diri merupakan usaha untuk menyelematkan dirinya sendiri secara internal dari problem-problem yang dihadapi, baik menyangkut tata kelola (management), peningkatan mutu dan daya saing, dan good governance. Sedangkan pelibatan masyarakat merupakan cermin bahwa madrasah merupakan usaha bersama komunitas masyarakat secara gotong royong.

Desentralisasi pendidikan (madrasah) memusatkan pada penyediaan lingkungan yang mendorong penerapan manajemen berbasis sekolah dan partisipasi masyarakat. Pada satu sisi, manajemen berbasis sekolah harus diterapkan agar adminitrasi pendidikan lebih dapat disesuaikan dengan kndisi lokal sejalan dengan desentralisasi. Pada sisi lain, manajemen berbasis sekolah juga menjadi kunci untuk menjamin mutu pendidikan karena peningkatan mutu hanya dapat dimulai dari proses belajarmengajar. Partisipasi masyarakat juga menjadi faktor lain yang menentukan mutu pendidikan karena mutu pendidikan mencerminkan tuntutan orang yang harus diberikan. ${ }^{3}$

${ }^{3}$ Depdiknas. Panduan Peningkatan Pendidikan Menengah Pertama di Indonesia. Jakarta: Direktorat Jenderal Manajemen Pendidikan Dasar dan Menengah dan JICA (Japan International Cooperation Agency), h. 57 


\section{B. Pemberdayaan Diri (Self Empowerment)}

Pemberdayaan diri (self empowerment) diorientasikan pada usaha untuk menyelesaikan problem-problem yang dihadapi setiap madrasah disesuaikan dengan kebutuhan dari masyarakatnya. Artinya pemberdayaan diri tetap berbasis kepada kebutuhan masyarakat, sehingga kecakapan yang dihasilkan pun memberikan manfaat secara luas kepada masyarakat. Hasil yang diperoleh dalam pemberdayaan diri ini adalah adanya adminitrasi pendidikan yang lebih dapat disesuaikan dengan kondisi lokal dan terjaminnya mutu pendidikan dan daya saing. Dengan pola ini, maka akan ditemukan hubungan yang korelatif antara analisis masalah dengan analisis kebutuhan.

Hal-hal yang bisa dikembangkan dari madrasah di komunitas marjinal adalah sebagai berikut:

\section{Sumber Daya Manusia}

Sumberdaya manusia yang dimiliki oleh madrasah biasanya sangat terbatas, baik jumlah pendidik dan tenaga pendidikan maupun kualifikasi yang dibutuhkan. Untuk meningkatkan SDM yang terbatas di komunitas marjinal, madrasah mesti menggunakan pendekatan biaya murah. Paling tidak, guru-guru juga harus memiliki jejaring dengan sekolah yang sudah maju. Di samping itu, diperlukan musyawarah guru mata pelajaran (MGMP) untuk mengevaluasi berbagai pengalaman dalam mengajar. MGMP bisa menjadi forum sharing pengalaman.

\section{Manajemen}

Tata kelola yang tidak baik di madrasah komunitas marjinal biasanya menjadi persoalan laten yang tak kunjung usai. Di sinilah, perlu ada pelatihan manajem madrasah yang diorientasikan pada otoritas sekolah untuk mengembangkan dirinya dengan kekhasan sendiri. Pengelolaan pun harus menggunakan prisnip akuntabilitas dan transparansi.

3. Kurikulum memenuhi penerapan KTSP (Kurrikulum Tingkat Satuan Pendidikan) dan life skill, (kecakapan hidup) agar siswa yang keluar dari madrasah itu bisa memiliki kekhasan dalam 
academic, social skill, vocasional skill (keterampilan) untuk menjawab persoalan-persoalan hidup di masyarakat.

4. Jaringan sekolah, bagaimana sekolah itu bisa membuat jaringan dengan masyarakat. Masyarakat terus digerakan perhatiannya terhadap sekolah. Inti jaringan yang dibentuk didasarkan pada pengembangan madrasah lebih menyeluruh, mulai dari pemerintah, madrasah, hingga masyarakat pada umumnya.

Pengembangan madrasah di komunitas marjinal bisa menggunakan pendekatan managemen berbasis sekolah (MBS). MBS dipandang sebagai alternatif dari pola umum pengoperasian madrasah yang selama ini memusatkan wewenang di kantor pusat dan daerah. MBS adalah strategi untuk meningkatkan pendidikan dengan mendelegasikan kewenangan pengambilan keputusan penting dari pusat dan dearah ke tingkat madrasah. Dengan demikian, MBS pada dasarnya merupakan sistem manajemen di mana madarasah merupakan unit pengambilan keputusan penting tentang penyelenggaraan pendidikan secara mandiri. MBS memberikan kesempatan pengendalian lebih besar bagi kepala madrasah, guru, murid, dan orang tua atas proses pendidikan di madrasah.

Dalam pendekatan ini, tanggung jawab pengambilan keputusan tertentu mengenai anggaran, kepegawaian, dan kurikulum ditempatkan di tingkat madrasah dan bukan di tingkat daerah, apalagi pusat. Melalui keterlibatan guru, orang tua, dan anggota masyarakat lainnya dalam keputusan-keputusan penting itu, MBS dipandang dapat menciptakan lingkungan belajar yang efektif bagi para murid. Dengan demikian, pada dasarnya MBS adalah upaya memandirikan madrasah dengan memberdayakannya. ${ }^{4}$

\section{Pelibatan Masyarakat (People Engagement)}

Pelibatan masyarakat memberikan otoritas yang kuat kepada madrasah untuk melaksanakan penyelenggaraan pendidikan. Dalam konsep ini, masyarakat sesungguhnya memiliki kemampuan untuk terlibat dalam proses pendidikan. Pemikiran inilah

4 Agus Dharma, Manajemen Berbasis Sekolah, Belajar Dari Pengalaman Orang Lain, Makalah tidak diterbitkan. 
yang menjadi dasar filosofi bagi seluruh argumen yang menghendaki peran masyarakat yang lebih besar dalam penyelenggaraan pendidikan. Sebab, masyarakat mempunyai suara dalam pembuatan keputusan, baik secara langsung maupun melalui intermediasi institusi legtimasi yang mewakili kepentingannya. Partisipasi seperti ini dibangun atas dasar kebebasan berasosiasi dan berbicara serta berpartisipasi secara konstruktif.

Memang pada kenyataannya, masih banyak pelibatan masyarakat yang bersifat top down, yaitu madrasah belum secara signifikan memberikan kebebasan yang penuh kepada masyarakat untuk terlibat dalam proses pendidikan. Padahal sejak dahulu kala, masyarakat dengan budaya gotong royong pada dasarnya aktif berpartisipasi. Masyarakat secara turun temurun telah berusaha menyelesaikan permasalahan yang dihadapi oleh komunitasnya. Masyarakat tradisional memiliki mekanisme untuk menyelesaikan persoalan komunitasnya secara partisipatif. Masyarakat terbiasa untuk terlibat (berpartisipasi) bahkan menyumbangkan sumber daya yang dimilikinya untuk menyelesaikan permasalahan atau kebutuhan komunitasnya. ${ }^{5}$ Tak heran, jika dalam prakteknya ada inisiatif yang dilakukan masyarakat untuk berpartisipasi dalam proses pendidikan di beberapa daerah.

Gambar 1: Skema Partisipasi Masyarakat

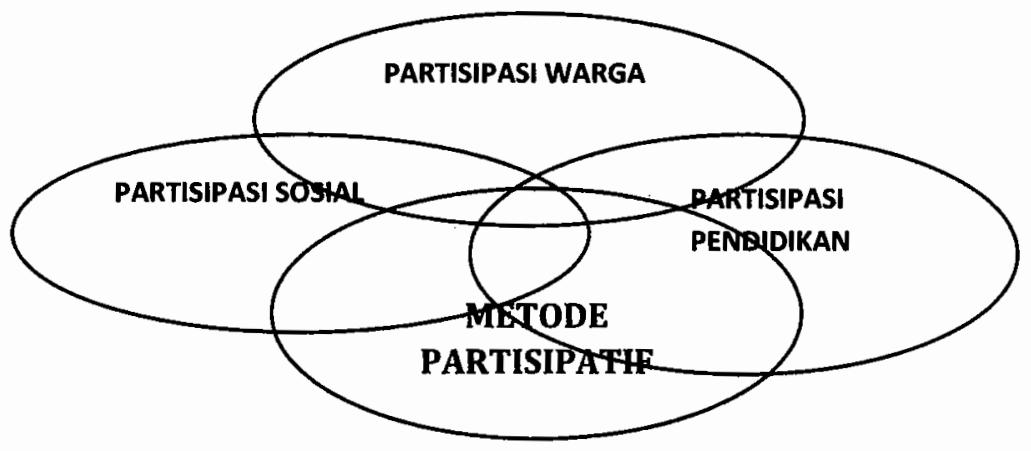

5 Pedoman Penyusunan Peraturan Daerah Mengenai Partisipasi, Melegalkan Partisipasi, BUILD (Breakthrough Urban Intiatives for Local Development) didukung oleh DEPDAGRI, UNDP, UN-HABITAT, edisi Desember (2002), hal. 6. 
Tabel 9.

Bentuk Pelibatan Masyarakat

\begin{tabular}{|c|c|c|c|c|}
\hline Tingkat & Penjelasan & Tujuan & $\begin{array}{l}\text { Strategi } \\
\text { Komunikasi }\end{array}$ & $\begin{array}{l}\text { Metode/ } \\
\text { Teknik }\end{array}$ \\
\hline $\begin{array}{l}\text { Pelibatan } \\
\text { (engagement): } \\
\text { Madrasah } \\
\text { bekerja dengan } \\
\text { warga di dalam } \\
\text { proses } \\
\text { penyusunan } \\
\text { kebijakan } \\
\text { madrasah agar } \\
\text { aspirasi warga } \\
\text { selalu } \\
\text { dipertimbangkan }\end{array}$ & $\begin{array}{l}\text { Penggunaan } \\
\text { alat-alat } \\
\text { untuk } \\
\text { memproses } \\
\text { informasi } \\
\text { pengambilan } \\
\text { keputusan } \\
\text { bersama }\end{array}$ & $\begin{array}{l}\text { Melibatkan } \\
\text { warga } \\
\text { dalam } \\
\text { penyelesaian } \\
\text { masalah } \\
\text { Melibatkan } \\
\text { warga } \\
\text { Dalam } \\
\text { pengambilan } \\
\text { keputusan } \\
\text { Mengembangkan } \\
\text { kapasitas dalam } \\
\text { melaksanakan } \\
\text { kebijakan } \\
\text { Memperbaiki } \\
\text { hasil } \\
\text { pelaksanaan }\end{array}$ & $\begin{array}{l}\text { Pertemuan } \\
\text { tatap muka } \\
\text { dengan warga } \\
\text { "Pertemuan" } \\
\text { on-line dengan } \\
\text { warga } \\
\text { Pendelegasian } \\
\text { kewenangan }\end{array}$ & $\begin{array}{l}\text { Musyawarah } \\
\text { warga } \\
\text { (public } \\
\text { deliberation) }\end{array}$ \\
\hline
\end{tabular}

Dengan alur yang partisipatif inilah, tata kelola madrasah tidak lagi menggunakan pendekatan bottom up (dari bawah), bukan di tangan orang-perorang di lingkungan madrasah, mulai dari perumusan (perencanaan-penganggaran), pelaksanaan, mau pun evaluasi. Minimnya peran dan partisipasi seluruh pelaku madrasah dan masyarakat dalam setiap pengambilan kebijakan menyebabkan masalah baru dalam implementasi.

Pengambilan keputusan selama ini hanya bisa diakses oleh kalangan tertentu saja di kalangan madrasah. Masyarakat umum dan sebagian besar pelaku madrasah kesulitan mengakses rencana yang disusun sebagai kebijakan pendidikan. Hal ini tentu mengurangi optimalisasi pelaksanaan, karena kebijakan yang diambil seringkali teralienasi dari kenyataan di lapangan.

Dalam konteks inilah, pendekatan yang bisa digunakan madrasah di komunitas marjinal adalah Pendidikan Berbasis Masyarakat. Yakni, pendidikan yang dikelola oleh masyarakat dengan memanfaatkan fasilitas yang ada di masyarakat dan menekankan 
pentingnya partisipasi masyarakat pada setiap kegiatan belajar serta bertujuan untuk menjawab kebutuhan masyarakat. Konsep dan praktek PBM tersebut adalah untuk mewujudkan masyarakat yang cerdas, terampil, mandiri dan memiliki daya saing dengan melakukan program belajar yang sesuai kebutuhan masyarakat. Dengan demikian, tenaga pendidikan (pihak-pihak terkait) harus melakukan akuntabilitas (pertanggungjawaban) kepada masyarakat. Pengembangan akuntabilitas terhadap masyarakat akan menumbuhkan inovasi dan otonomi dan menjadikan pendidikan berbasis pada masyarakat (community based education).

Pengembangan pendidikan berbasis masyarakat akan bermanfaat:

1) membantu pemerintah dalam mobilisasi SDM setempat dan dari luar serta meningkatkan peranan masyarakat untuk mengambil bagian lebih besar dalam perencanaan, pelaksanaan, dan evaluasi pendidikan di semua jenjang, jenis dan jalur pendidikan.

2) Mendorong perubahan sikap dan persepsi masyarakat terhadap rasa kepemilikan madrasah, tanggung jawab kemitraan, toleransi dan kesediaan menerima sosial budaya.

3) Mendukung inisiatif pemerintah dalam meningkatkan dukungan masyarkat terhadap madrasah, khususnya orang tua dan anggota masyarkat lainnya melalui kebijakan desentralisasi.

4) Mendukung peranan masyarakat mengembangkan inovasi kelembagaan untuk melengkapi, meningkatkan, dan mensinergikan dengan peran madrasah, dan untuk meningkatkan mutu dan relevansi, membuka kesempatan lebih besar dalam memperoleh pendidikan.

Partisipasi masyarakat tersebut kemudian dilembagakan dalam bentuk dewan pendidikan dan komite sekolah/madrasah. Dewan pendidikan adalah lembaga mandiri yang beranggotakan berbagai unsur masyarakat yang peduli terhadap pendidikan. Sedangkan komite sekolah/madrasah adalah lembaga mandiri yang terdiri dari unsur orang tua/wali peserta didik, komunitas sekolah, serta tokoh masyarakat yang peduli pendidikan. Dewan 
pendidikan berperan dalam peningkatan mutu pelayanan pendidikan, dengan memberikan pertimbangan, arahan, dan dukungan tenaga, sarana dan prasarana, serta pengawasan pendidikan pada tingkat nasional, provinsi dan kabupaten/kota yang tidak mempunyai hubungan hirarkis. Sedangkan peningkatan mutu pelayanan di tingkat satuan pendidikan peran-peran tersebut menjadi tanggungjawab komite sekolah/madrasah. ${ }^{6}$

\section{PENUTUP}

Pengembangan pendidikan madrasah di komunitas sudah sepantasnya berbeda perlakuannya dengan komunitas lain yang lebih banyak mendapatkan akses pendidikan yang memadai. Di komunitas yang masyarakatnya sulit mendapatkan akses pembangunan, terpencil, dan jauh dari infrastruktur yang memadai, seperti Jayapura maka layanan pendidikan madrasahnya lebih diarahkan pada pemberdayaan diri, terutama untuk memecahkan persoalannya sendiri secara lebih mandiri dengan melihat analisis persoalan dan tingkat kebutuhan yang diharapkan. Dalam posisi ini, pemerintah bertindak sebagai pendamping yang akan memberikan support secara langsung maupun tidak langsung terhadap peningkatan pendidikan madrasah di komunitas marjinal.

Oleh karena itu, tingkat pelibatan masyarakatnya lebih besar karena kultur yang dimilikinya masih kuat nilai-nilai keswadayaan dan gotong-royong sehingga model madrasah yang dikembangkan merupakan pendidikan masyarakat. Madrasah di komunitas marjinal akan memberikan partisipasi masyarakat sebagai bagian dari pengembangan ke arah yang lebih baik.

${ }^{6}$ Abu Hafdi Efendi. 2008. Pendidikan Berbasis Masyarakat. Makalah tidak diterbitkan. 


\section{SUMBER BACAAN}

Depdiknas. Panduan Peningkatan Pendidikan Menengah Pertama di Indonesia. Jakarta, Direktorat Jenderal Manajemen Pendidikan Dasar dan Menengah dan JICA (Japan International Cooperation Agency.

Dharma, Agus. Manajemen Berbasis Sekolah, Belajar Dari Pengalaman Orang Lain. Makalah tidak diterbitkan.

Efendi, Abu Hafdi (2008): Pendidikan Berbasis Masyarakat. Makalah tidak diterbitkan.

Laurence Sullivan, "Affirmative Action and Otsus", lihat www.papuaweb.org/dlib/lap/sullivan/en/affirmative.rtf.

Mark Daniel dan Fletcher Linder, "Marginal People", dalam http://www.answers.com/topic/marginal-people. Diakses terakhir 5 Januari 2009.

Pedoman Penyusunan Peraturan Daerah Mengenai Partisipasi, Melegalkan Partisipasi, BUILD (Breakthrough Urban Intiatives for Local Development) didukung oleh DEPDAGRI, UNDP, UN-HABITAT, edisi Desember (2002). 